\title{
Summer distribution and abundance of the giant devil ray (Mobula mobular) in the Adriatic Sea: Baseline data for an iterative management framework
}

\author{
Caterina Maria Fortuna ${ }^{1}$, Laurence Kell ${ }^{2}$, Draško Holcer ${ }^{3,4}$, Simonepietro Canese ${ }^{1}$, \\ Elio Filidei Jr. ${ }^{1}$, Peter Mackelworth ${ }^{3}$, Greg Donovan ${ }^{5}$ \\ ${ }^{1}$ Italian National Institute for Environmental Protection and Research (ISPRA), via Vitaliano Brancati 48, 00144 Roma, \\ Italy. E-mail: caterina.fortuna@ isprambiente.it \\ ${ }^{2}$ ICCAT Secretariat, Corazón de María 8, 28002 Madrid, Spain. \\ ${ }^{3}$ Blue World Institute of Marine Research and Conservation, Kaštel 24, HR-51551 Veli Lošinj, Croatia. \\ ${ }^{4}$ Croatian Natural History Museum, Demetrova 1, HR-10000 Zagreb, Croatia. \\ ${ }^{5}$ International Whaling Commission, 135 Station Road, Impington, Cambridge CB24 9NP, UK.
}

\begin{abstract}
Summary: The giant devil ray (Mobula mobular) is a poorly understood protected endemic species of the eastern AtlanticMediterranean region. However, to date there are no range-wide management actions in place. This paper provides the first overview of the summer distribution and abundance of this species and other Myliobatiformes within the Adriatic Sea based on an aerial survey. Although the survey's primary targets were cetaceans and sea turtles, the study showed that it was possible to use the survey to monitor other species. Abundance estimates are derived using conventional distance sampling analysis. Giant devil rays were observed mainly in the central-southern Adriatic ( $88 \%$ of total sightings). A total of 1595 giant devil rays were estimated in the central-southern Adriatic Sea [coefficient of variation $(\mathrm{CV})=25 \%$, uncorrected estimate for perception and availability bias]. When corrected for availability bias the number of specimens was estimated at 3255 $(\mathrm{CV}=56 \%)$. Population growth rate was estimated using life history traits and a sensitivity analysis was conducted to evaluate the benefit of improving biological knowledge on this data-poor species. A power analysis showed that a long-term commitment to an aerial survey would be necessary to monitor population trends. Conservation implications and future work, including how the study could be used to conduct an ecological risk assessment are discussed.
\end{abstract}

Keywords: aerial survey; conservation; conventional distance sampling; ecological risk assessment; management; Myliobatiformes; sensitivity; power analysis.

Distribución estival y abundancia de la gran manta raya (Mobula mobular) en el mar Adriático: datos de base para un marco de gestión iterativo

Resumen: La manta raya gigante (Mobula mobular) es una especie endémica protegida poco conocida de la región del Atlántico oriental-Mediterráneo. Sin embargo hasta la fecha no hay acciones de gestión que cubran todo su rango. Este artículo proporciona la primera visión de conjunto de la distribución y abundancia estival de esta especie y otras Myliobatiformes en el mar Adriático basada en un censo aéreo. Aunque los objetivos principales del censo eran cetáceos y tortugas marinas, el estudio mostró que era posible usar el censo para monitorizar otras especies. Las estimas de abundancia se derivaron utilizando análisis convencional de muestreo de distancias. Las manta rayas gigantes se observaron principalmente en el Adriático central y sur ( $88 \%$ de los avistamientos totales). Se estimaron un total de 1595 mantas rayas gigantes en el mar Adriático central-sur ( $\mathrm{CV}=25 \%$, estima no corregida para los sesgos de percepción y de disponibilidad). Cuando se corrigió para el sesgo de disponibilidad el número de especímenes se estimó en 3255 (CV=56\%). La tasa de crecimiento de la población se estimó usando aspectos de la historia natural y se realizó un análisis de sensibilidad para evaluar el beneficio de mejorar el conocimiento biológico de esta especie de la que hay tan pocos datos. Un análisis de potencia mostró que sería necesario un compromiso a largo plazo para realizar censos aéreos para monitorizar las tendencias de la población. Se discuten las implicaciones para la conservación y trabajo futuro, incluyendo cómo se podría utilizar este estudio para llevar a cabo una evaluación ecológica de riesgo.

Palabras clave: censo aéreo; conservación; muestreo convencional de distancias; evaluación ecológica de riesgo; gestión; Myliobatiformes; sensibilidad; análisis de potencia.

Citation/Como citar este artículo: Fortuna C.M., Kell L., Holcer D., Canese S., Filidei Jr. E., Mackelworth P., Donovan G. 2014. Summer distribution and abundance of the giant devil ray (Mobula mobular) in the Adriatic Sea: Baseline data for an iterative management framework. Sci. Mar. 78(2): 227-237. doi: http://dx.doi.org/10.3989/scimar.03920.30D

Editor: P. Sartor.

Received: July 15, 2013. Accepted: March 7, 2014. Published: May 30, 2014. 
Copyright: (C) 2014 CSIC. This is an open-access article distributed under the Creative Commons Attribution-Non Commercial Lisence (by-nc) Spain 3.0.

\section{INTRODUCTION}

The conservation status of a species or population can be defined in several ways. For example, the IUCN Red List of Threatened Species classifies species into categories (ranging from "Data Deficient" to "Critically Endangered"; see http://www.iucnredlist.org/) using criteria such as rate of decline, population size and distribution. These categories require knowledge of the abundance, population structure, ecology and life history parameters, as well as anthropogenic or other factors that may threaten the population. Acquiring this knowledge for elasmobranchs is particularly difficult, resulting in a near absence of the data that would be required to undertake full population assessments (Dulvy et al. 2008). Although there are some regional, temporal and geographical restrictions for directed elasmobranch fisheries (e.g. the European Council Regulation (EU) no. 57/2011, the UN ban on large pelagic driftnets in 1992, and the ban on finning by several regional fishery management organizations such as GFCM and ICCAT), many populations are still subject to unsustainable levels of exploitation (e.g. Dulvy et al. 2008, Ferretti et al. 2010).

While the strengths and weaknesses of generic conservation systems, such as that of the IUCN, are open to debate, many status classifications lack sufficient quantitative data to inform actual management and conservation actions. For example, assessments are often at the species rather than the population level, which is inappropriate for developing mitigating actions and evaluating the success of management. Moreover, for poorly understood species, classifications often rely on inferred and qualitative evaluations (see Camhi et al. 2009), which can lead to inconsistencies among and within taxa. Such inconsistencies make it difficult to compare population status within species, for instance using fisheries management reference points with the IUCN criteria (Rice and Legacè 2007).

One approach to move towards quantitative assessments with limited data is the use of ecological risk assessments (ERAs) (see Cortés et al. 2010, Arrizabalaga et al. 2011, Hobday et al. 2011) to identify populations at risk and fisheries of concern. ERAs combine biological productivity analysis with susceptibility analysis to assess the likelihood of a population being impacted by threats such as direct or incidental capture.

The giant devil ray (Mobula mobular) is included in Appendix II of the Bern Convention (1982) and in Annex II of the "Protocol concerning Specially Protected Areas and Biological Diversity in the Mediterranean" (1996) of the Barcelona Convention (1976). These listings provide a framework for the development of national protection measures and for the creation of ad hoc international management schemes. While many States have fulfilled their formal legal commitments in respect of the protection of the giant devil ray (Notarbartolo di Sciara et al. 2006), to date there are no national or international management measures or moni- toring programmes in place. For example, there are no fishing prohibitions on Mobula mobular and the species is not included in the Data Collection Framework (Council Regulation (EC) 199/2008); this is in direct contrast to the situation for the closely-related Manta birostris (see Council Regulation (EC) 692/2012 and Council Regulation (EC) 39/2013).

Information on the biology of the giant devil ray is scarce (Couturier et al. 2012). The limited data have largely been obtained from opportunistic measurements of a few specimens caught at various locations in the last century (e.g. Couturier et al. 2012, Holcer et al. 2013). By analogy, the giant devil ray is assumed to be a typical $K$-selected species with a long reproductive cycle and low fecundity.

The sparse information on its distribution is again based largely on opportunistic observations of varying reliability (Notarbartolo di Sciara et al. 2006, Couturier et al. 2012, Holcer et al. 2013). It is considered to be endemic to the eastern Atlantic and Mediterranean and its extension into Atlantic waters has never been confirmed (Notarbartolo di Sciara et al. 2006). Most sighting reports are for deep pelagic waters, but there are also occasional records from the shallow waters of the northern Adriatic Sea, the Gulf of Gabes and the southwestern coastal part of Sardinia (Bradai and Capapé 2001, Storai et al. 2011, Holcer et al. 2013).

While the giant devil ray is not considered to have been subjected to a directed fishery, 'incidental' catches in the otherwise highly selective Sicilian swordfish harpoon fishery were reported until the late 1990s (Bauchot 1987, Celona 2004); despite the absence of abundance data, the level of exploitation was considered 'low' by Bauchot (1987). It should be noted that a recent mass-stranding of about 500 specimens along the coast of the Gaza Strip (Palestine) appeared to be the result of a recently developed unregulated fishery taking advantage of winter aggregations (Couturier et al. 2013)

With respect to incidental catches, there have been numerous reports for purse-seines, long-lines, trammel nets, mid-water/pelagic trawls and traditional tuna traps in addition to IUU (illegal, unregulated and unreported) driftnet fisheries (e.g. Marano et al. 1983, Akyol et al. 2005, Holcer et al. 2013). Bycatch from the large pelagic driftnet fishery was reported until two decades ago (Di Natale et al. 1995, Di Natale 1998).

The IUCN Red list classification for the giant devil ray is 'Endangered'. This was based mainly on 'expert judgement' due to the scarcity of data; it took into account a combination of factors including limited range, inferred low densities and presumed unsustainable interactions with IUU fisheries (Notarbartolo di Sciara et al. 2006).

Expert judgement evaluations should only be a warning sign and a prelude to obtaining the necessary data to undertake a quantitative assessment of the effect of anthropogenic mortality and the need for management measures. As a minimum, this requires estimates 
of abundance (and/or series of relative abundance values), productivity and the level of human-induced mortality.

There are no well-developed methods to estimate the abundance of Mobula. Aerial surveys using distance sampling techniques have been used for some time to estimate the abundance of a variety of airbreathing marine species, including marine mammals, sea birds and sea turtles (e.g. see review in Buckland et al. 2004). More recently, they have been applied to certain fish species that spend time close to the sea surface, including tuna and elasmobranchs (e.g. Cliff et al. 2007, Rowat et al. 2009, Bonhommeau et al. 2010). The giant devil ray spends up to half of its time near the surface (Canese et al. 2011) and was thus considered a suitable candidate for aerial surveys, especially in waters with high clarity, such as the Adriatic Sea.

The Adriatic Sea is a semi-enclosed basin of 133000 $\mathrm{km}^{2}$ in area characterized by three biogeographic regions (Bianchi 2007):

- the shallow northern continental waters (less than $100 \mathrm{~m}$ in depth), strongly influenced by the Po river plumes, with lower salinity, lower water temperature and high productivity;

- the central Adriatic characterized by bathymetries ranging between 100 and $270 \mathrm{~m}$ in depth, and influenced by the inflow of Levantine Intermediate Water (LIW); and

- the deep pelagic southern Adriatic, with steep slopes and water depths up to $1200 \mathrm{~m}$, with warmer waters and higher salinity.

The three sub-regions also have noticeable differences in sea current gyres (Cushman-Rosin et al. 2001, Bianchi 2007). While the northern and central subregions represent about half of the sea surface of the entire Adriatic Sea, they encompass only $20 \%$ of its volume (Cushman-Rosin et al. 2001). These sub-region characteristics affect the distribution of megafauna and their prey. Holcer et al. (2013) suggested that seasonal observations in the central-south Adriatic coincided with the distribution of potential prey (small pelagic fish and macrozooplankton). Giant devil ray distribution within the Adriatic was thought to be similar to that of other pelagic species, including cetaceans [e.g. the Cuvier's beaked (Holcer et al. 2007) and sperm whales (Bearzi et al. 2011)], chelonids [e.g. the leatherback turtle (Lazar et al. 2008)] and other species with an obligate epipelagic phase in oceanic ecosystems, such as green turtles (Lazar et al. 2004, 2010) and loggerhead turtles (Casale et al. 2007).

This paper provides the first overview of the summer distribution and abundance of the giant devil ray and other Myliobatiformes in the Adriatic Sea. Based on systematic aerial survey data, it proposes an iterative framework for the development of a reliable assessment of the conservation status of the giant devil ray, the determination of appropriate monitoring options and the development and evaluation of any necessary management measures. It is intended to stimulate future targeted work to assess the status of the species and any conservation and management needs.

\section{MATERIALS AND METHODS}

\section{Distribution and abundance}

Data were collected during a survey for which the primary target species were cetaceans and sea turtles. Given the ecological characteristics of the giant devil ray, two strata were chosen: (1) the entire Adriatic Sea $\left(133000 \mathrm{~km}^{2}\right)$; and (2) the "central and southern Adriatic", i.e. the pelagic portion of the Adriatic Sea (about $88400 \mathrm{~km}^{2}$ ). Both strata were covered by 20 $\mathrm{km}$-spaced parallel transects with a random start point (Fig. 1) providing equal coverage probability using the Distance 6.0 software (Buckland et al.

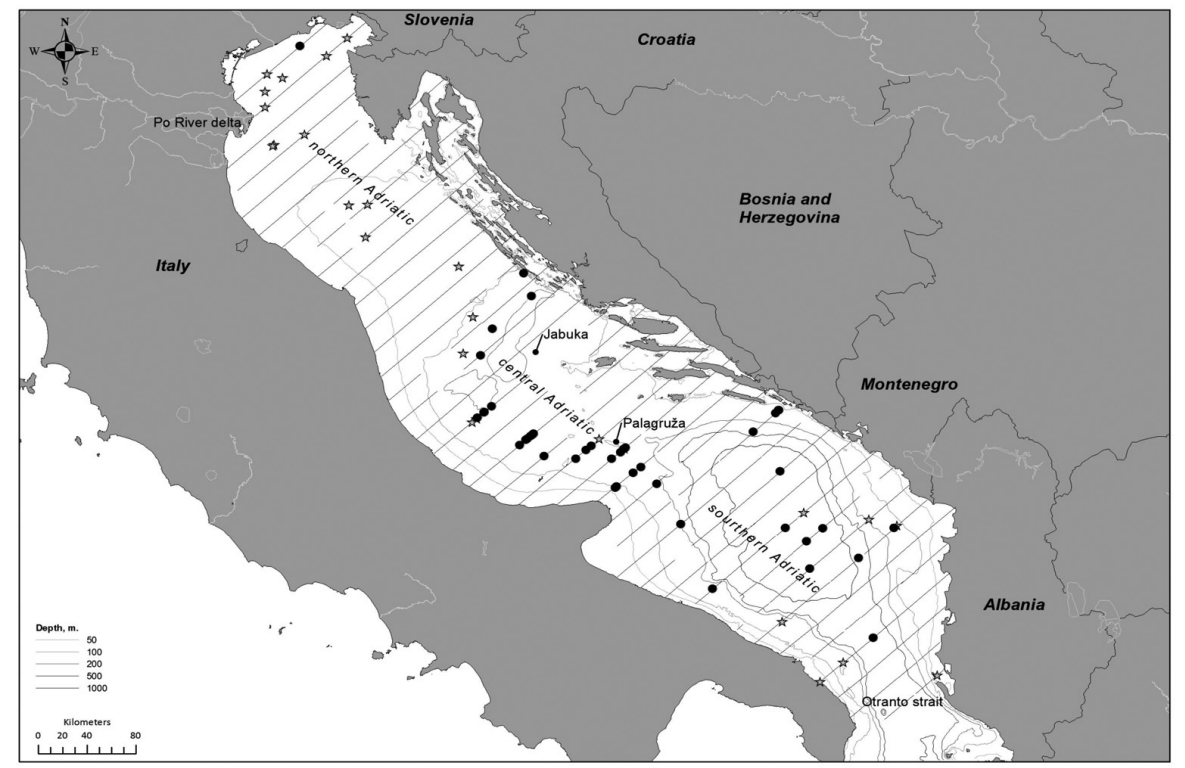

Fig. 1. - Aerial survey (1-16 August 2010): on-effort track-lines with Beaufort state >3; on- and off-effort sightings of giant devil ray (black dots) and Myliobatiformes (grey stars). The dashed line indicates the separation between the northern and the central Adriatic portions of the basin, delimitating the central and southern Adriatic sub-stratum. 
2004, Thomas et al. 2010; http://www.ruwpa.st-and. ac.uk/distance/). Survey design and data collection followed the standard line-transect distance sampling methodology (Buckland et al. 2004).

The survey took place between 31 July and $16 \mathrm{Au}-$ gust 2010 when weather conditions were expected to most likely allow coverage of the predetermined tracklines under acceptable conditions for the target species (i.e. sea states of $\leq 3$ and good visibility). A twin engine high-wing aircraft (Partenavia P-68) equipped with two bubble windows was used as the research platform. The observer team consisted of three researchers: two searching for animals through opposite lateral bubble windows and a third recording data onto a semi-automated logging system. Based on experience from surveys elsewhere, the plane flew at an altitude of approximately $200 \mathrm{~m}(650 \mathrm{ft})$ with a ground speed of about $185 \mathrm{~km} / \mathrm{h}$ (100 knots)-precise height and speed was obtained from the GPS records. Only 'oneffort' encounters (searching along the predetermined track-lines under acceptable conditions) were used for the final abundance estimation. The distance between transects $(20 \mathrm{~km})$, survey speed and the average distance covered daily by giant devil rays $(2.5-3.7 \mathrm{~km} /$ day, Canese et al. 2011) minimize the risk of double counting animals/groups.

Data recorded, in addition to the GPS data, were (1) time of sighting when abeam; (2) species identification (discussed below); (3) school size; (4) declination angles measured using Suunto PM-5/360PC inclinometers on the observed animals when abeam (to allow calculation of perpendicular distance of the sighting from the track-line); (5) environmental information (including sea state, turbidity, cloud cover, etc.); (5) effort (e.g. whether plane is 'on-effort', i.e. circling to confirm data, or 'off-effort', i.e. transiting or in unacceptable conditions) and positional/time data; and (6) approximate estimated disc width (DW) category ("0.5-1 m", "2-3 m" and ">3 m") using average lengths of sea turtles, striped dolphins and bottlenose dolphins as a reference.

Conventional distance sampling (CDS) analysis was applied and data were analysed using the Distance 6.0 software. In summary, density was estimated from:

$$
\hat{D}=\frac{n \bar{s}}{2 \hat{w} L}
$$

where $n$ is the number encounters on-effort; $s$, the school size; $L$, the length of transect; and $w$, the effective strip half width.

The effective strip width was estimated by fitting a detection function to the distribution of perpendicular distances of sightings from the track-line. Since the reliability of the detection function analysis is dependent upon sample size, we chose to use all available sighting data for Myliobatiformes. Myliobatiformes other than M. mobular are somewhat smaller and more difficult to detect and their inclusion will not introduce any major bias into the detection function and hence $w$. The best model fit was chosen using Akaike's Information Criterion (AIC), as proposed in Buckland et al. (2004). Total uncorrected abundance $(\hat{N})$ was then calculated from the density estimate and the surface of surveyed area.

Total abundance corrected $(\hat{N})$ for availability bias $(\hat{a})$ and its coefficient of variation

$$
C V\left(\hat{N}_{c}=\frac{\hat{N}}{\hat{a}}\right)
$$

were calculated as follows: $\hat{N}_{c}=\frac{\hat{N}}{\hat{a}}$ and

$$
C V\left(\hat{N}_{c}\right)=\sqrt{C V\left(\hat{N}_{c}\right)^{2}+C V(\hat{a})^{2}} .
$$

\section{Species identification}

Whenever possible, Myliobatiformes were identified to species. In the Adriatic, adult giant devil rays $(\mathrm{DW}=2-4 \mathrm{~m})$ are easily identifiable from the air at 200 $\mathrm{m}$ in sea state $\leq 3$ (Fig. 2). In addition to the dark stripe on the head and the two obvious cephalic fins extending beyond its head, this species is characterized by a white lateral ventral colouration apparent when it is filter feeding. When observed dorsally, it appears to be a bluish black to brown colour, with a distinctive darker and lighter pattern between the eyes.

Smaller animals ( $\mathrm{DW} \leq 2 \mathrm{~m}$ ) may include young giant devil rays, bull rays (Pteromylaeus bovinus), common eagle rays (Myliobatis aquila) or the dasyatid pelagic sting ray (Pteroplatytrygon violacea), which are also present in the Adriatic Sea (Fortuna et al. 2010). The bull and common eagle rays, although generally similar in shape to the giant devil ray, are smaller and lack cephalic fins (adult DW 100-170 cm and 40-80 cm, respectively; Jardas et al. 2004, Dulčić et al. 2008). The sting ray is also smaller ( $80 \mathrm{~cm}$ maximum) and has a more discoid shape (Bauchot 1987, Mollet 2002).

Abundance estimates are presented for (1) adult giant devil rays in central-southern Adriatic; and (2) all Myliobatiformes combined, in the entire Adriatic Sea.

\section{Bias correction}

The CDS assumes that all animals on the track-line are seen (commonly stated as $g(0)=1$ ). This is rarely the case in any survey and certainly not the case for animals that do not spend all their time at the surface. There are two primary categories of bias affecting $g(0)$ :

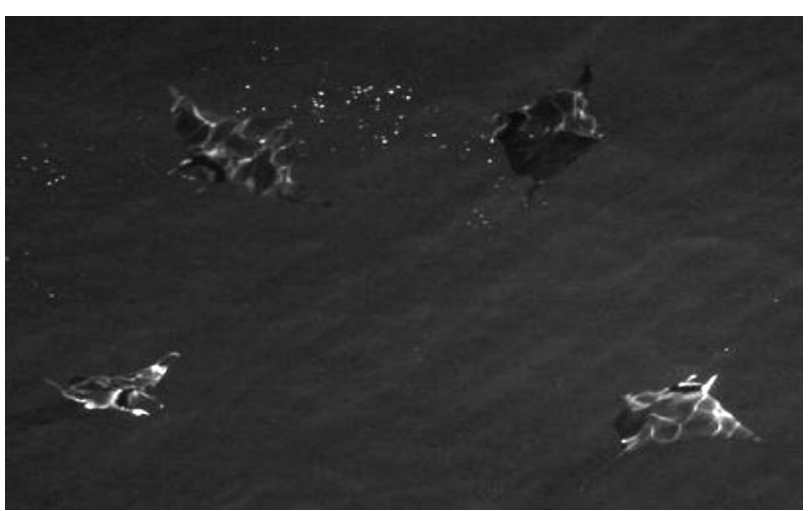

Fig. 2. - Four giant devil rays encountered in the southern Adriatic Sea. 
Table 1. - Life history parameters and ecological aspects of the giant devil ray (Mobula mobular). * These are actual measurements: not estimates or rough measures/estimates.

\begin{tabular}{|c|c|c|c|c|}
\hline Parameter & Size & Sex & $\mathrm{n}$ & Reference \\
\hline Embryo disc width, $\mathrm{cm}^{*}$ & 61 & - & 1 & Capapé and Zaouali 1976 as cited in Notarbartolo di Sciara 1987 \\
\hline \multirow{4}{*}{ Juvenile disc width, $\mathrm{cm}^{*}$} & 165 & - & 1 & Bruni 2006 \\
\hline & 147 & M & 1 & Notarbartolo di Sciara 1987 \\
\hline & 166 & M & 1 & Notarbartolo di Sciara and Serena 1988 \\
\hline & 131 & $\mathrm{M}$ & 1 & Zaccaroni et al. 2007 \\
\hline \multirow[t]{8}{*}{ Adult disc width, $\mathrm{cm}^{*}$} & 230 & - & 1 & Zaccaroni et al. 2007 \\
\hline & 300 & $\mathrm{~F}$ & 1 & Capapé and Zaouali 1976 as cited in Bradai and Capapé 2001 \\
\hline & 220 & M & 1 & Capapé et al. 1990 as cited in Bradai and Capapé 2001 \\
\hline & 290 & M & 1 & Bradai and Capapé 2001 \\
\hline & 209 & $\mathrm{~F}$ & 1 & Bradai and Capapé 2001 \\
\hline & 340 & $\mathrm{~F}$ & 1 & Notarbartolo di Sciara and Serena 1988 \\
\hline & 520 & - & 1 & Pellegrin 1901 as cited in Notarbartolo di Sciara 1987 \\
\hline & 455 & - & 1 & Lozano Rey 1928 as cited in Notarbartolo di Sciara 1987 \\
\hline \multirow{2}{*}{ Mean adult disc width, $\mathrm{cm}$} & 320.5 & Both & 8 & Mean of the previous 8 historical records. \\
\hline & 264.8 & Both & 6 & Mean of the previous 8 historical records, except 1901 and 1928 accounts. \\
\hline Length at birth, $\mathrm{cm}$ & 152.3 & - & 4 & Mean of 4 records on juvenile DW (see above) \\
\hline Weight at birth, $\mathrm{kg} *$ & 35 & M & 1 & Notarbartolo di Sciara and Serena 1988 \\
\hline Maximum length $\left(L_{\max }\right), \mathrm{cm}^{*}$ & 520 & - & 1 & Pellegrin 1901 as cited in Notarbartolo di Sciara 1987 \\
\hline Reproductive strategy (mobulids) & \multicolumn{3}{|c|}{ Aplacental viviparous } & Notarbartolo di Sciara et al. 2006 \\
\hline Average litter size & \multicolumn{3}{|c|}{1} & Notarbartolo di Sciara et al. 2006 \\
\hline Pregnancy duration & \multicolumn{3}{|c|}{ Unknown } & Notarbartolo di Sciara et al. 2006 \\
\hline Fecundity rate & \multicolumn{3}{|c|}{ Unknown } & Notarbartolo di Sciara et al. 2006 \\
\hline Length at maturity $\left(L_{\infty}\right), \mathrm{cm}$ & \multicolumn{3}{|c|}{ Unknown } & Notarbartolo di Sciara 1987 \\
\hline
\end{tabular}

(1) availability bias, where the diving behaviour of the animal renders it unavailable to be seen by the observers; and (2) perception bias caused by observers missing animals that in principle are available to be seen (i.e. they are at the surface as the plane passes over). However, if appropriate data are available these biases can be accounted for and thus an unbiased estimate of absolute abundance can be obtained. It should be noted that if a time series of relative abundance estimates is required (e.g. to estimate trends), then the $g(0)$ issue can be ignored if it can be assumed that it does not change over time.

Availability bias was corrected using time depth recorder data from Canese et al. (2011). who tagged three animals within the Tyrrhenian Sea and Sicily Channel between June and October 2007. These animals spent approximately $49 \%(\mathrm{SD}=0.25)$ of their time between 0 and $10 \mathrm{~m}$ depth. In the Adriatic Sea in summer, the limpidity of the northern offshore Italian waters normally ranges between 2 and $10 \mathrm{~m}$ (Casellato et al. 2005, Anonymous 2006). On the Croatian side it normally ranges from 11.7 to $17.5 \mathrm{~m}$ in summer 2010 (IOR 2011). These water characteristics allow for the potential sighting of animals below but near the surface. As an initial correction for the availability bias, $0.49(\mathrm{SD}=0.25)$ was applied. While the availability bias correction appreciably increases the point estimate, it also substantially increases the CV.

Perception bias can be corrected by using independent observer approaches (e.g. Buckland et al. 2004). However, the limitations of the sighting platform prevented collection of independent observer data. Not correcting for this bias will result in an underestimate of true abundance, to an unknown degree.

\section{Population growth rate analysis}

The sparse information on the biology of the giant devil ray is summarized in Table 1 . Disc width maximum size and average DW length at birth were 520 $\mathrm{cm}$ and $152 \mathrm{~cm}$, respectively. Length at maturity is unknown as is frequency of reproduction (a single pup is believed to be the norm). As for many fish species, natural mortality $(M)$ is unknown.

As an initial step towards developing a more quantitative assessment approach, growth was assumed to follow the von Bertalanffy (1938) growth curve:

$$
L_{t}=L_{\infty}\left(1-\exp ^{\left(-k\left(t-t_{0}\right)\right)}\right)
$$

where $k$ is the growth rate, $L_{\infty}$ is the asymptotic length and $t_{0}$ is a parameter of the von Bertalanffy growth formula, which represents the time at which the size is equal to 0 . We therefore used $L_{0}$, which can be derived from $t_{0}$, i.e.

$$
t_{0}=\log \left(\left(1-\frac{L_{0}}{L_{\infty}}\right) / k\right)
$$

In the following analyses all lengths and lengthbased parameters (e.g. $L_{\infty}$ ) were based on disc width (DW). Empirical studies have shown that life history parameters, such as $L_{\infty}, k$, maturity and natural mortality, are correlated and can be used to obtain estimates for data-poor stocks (e.g. Roff, 1984, Jensen 1996, Reynolds et al. 2001). Therefore, due to the lack of data on life history parameters for $M$. mobular, lengthbased parameters were derived by fitting linear regressions to data from related species and families. $L_{\infty}$ was derived from maximum size (Fig. 3A) and $\mathrm{k}$ from $L_{\infty}$ (Fig. 3C) using data on the families Myliobatidae and Rajidae in FishBase (Froese and Pauly 2012) and length-at-maturity from $L_{\infty}$ (Fig. 3B) using data on the Mobula genus from Couturier et al. (2012). These relationships (see linear regressions fitted in Figures 3a, b and c) provide estimates for $L_{\infty}$, length at maturity and $k$ of $880 \mathrm{~cm}, 320 \mathrm{~cm}$ and $k=0.09$ per year, respectively. Owing to the large size of $M$. mobula, in some cases this required extrapolation, but the extrapolations did not result in excessively large confidence limits and so were not rejected (Gislason 2010). Life history param- 

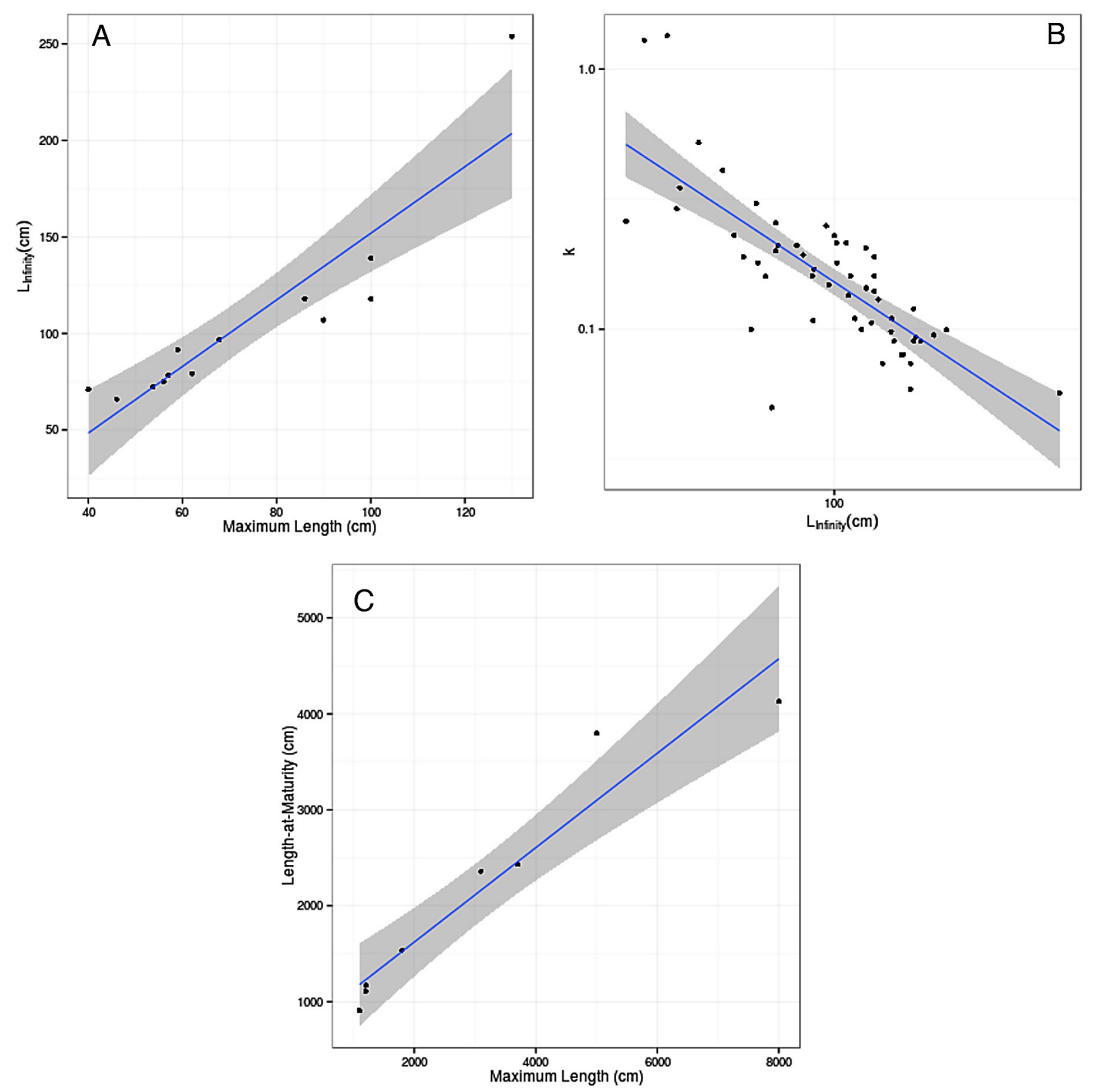

Fig. 3. - A, plots of $L_{\infty} v s$ maximum recorded length for Rajidae; B, $k v s L_{\infty}$ on the log scale for Rajidae and Myliobatidae; and C, length at maturity vs maximum recorded length for Mobula spp. Lines are linear regressions with $95 \%$ confidence interval. Data used in A and B are from Fishbase (Froese and Pauly 2012); data used in C are from Couturier et al. (2012).

eters also allow an approximate rate of natural mortality to be derived from life history 'invariants' (e.g. Beverton and Holt 1959, Jensen 1996), i.e.

$$
M=1.5 k
$$

where $k$ is the growth coefficient from the von Bertalanffy growth equation. Methods for estimating approximate size-dependent natural mortality vectors are also available (e.g. Peterson and Wroblewski 1984, Lorenzen 2000). However, an increase in $M_{0}$ and a reduction in fecundity have the same effect, i.e. they reduce recruitment, so to simplify this already exploratory analysis we considered recruitment, rather than $M_{0}$ and fecundity separately.

The population growth rate $(r)$ was estimated in the standard manner from the Leslie Matrix $(A)$, a transition matrix with columns representing age classes (Caswell 1989), i.e. $N_{t+1}=A N_{t}$, where $N_{t}$ is a vector describing the

$$
A=\left(\begin{array}{ccccc}
s_{0} f_{1} & s_{0} f_{2} & \cdots & s_{0} f_{m-1} & s_{0} f_{m} \\
s_{1} & 0 & \cdots & 0 & 0 \\
0 & s_{2} & \cdots & 0 & 0 \\
\vdots & \cdots & \ddots & 0 & 0 \\
0 & 0 & \cdots & s_{m-1} & 0
\end{array}\right)
$$

$r$ can be derived from $\lambda$, the dominant eigenvalue of $A$ :

$$
r=\log (\lambda)
$$

For a given value of $r$ the population doubling time is:

$$
T_{d}=\log (2) / \log (1+r)
$$

Since nothing is known about the breeding frequency of $M$. mobular, 1.5 years, the mean value provided for the closely-related Manta birostris (Dulvy et al. 2008) was used in this exploratory approach.

Assuming the relationships described above, we conducted a sensitivity analysis in which parameters were varied in turn, to examine the importance of the levels of uncertainty for the various parameters.

\section{Power analysis}

When designing monitoring programmes, it is important to determine what magnitude of population changes, should they occur, is detectable by proposed survey approaches over given time scales. Power analyses can be undertaken to evaluate the survey $\mathrm{CV}$ and frequency required to be reasonably certain to detect a given change in population size (Gerrodette 1987). Here we chose to examine a significance level of 5\% and a detection power of $60 \%$ based on conventional practice. Survey CVs considered were $20 \%$ and $30 \%$. 


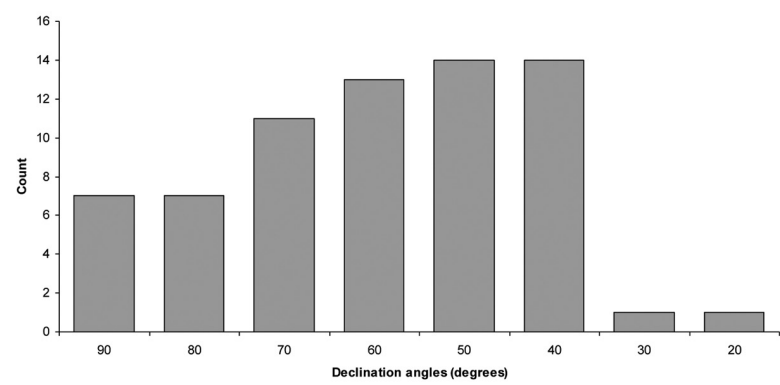

Fig. 4. - Distribution of recorded sighting declination angles (abeam) for all Myliobatiformes.

\section{RESULTS}

\section{Sightings and distribution}

Figure 1 shows the transect lines covered on-effort (Beaufort $\leq 3$ ).

A total of 68 sightings ( 56 on-effort) of all Myliobatiformes were obtained. The mean group size of Myliobatiformes was 1.1 animals $(\mathrm{SD}=0.49$; range $=1-4)$. Within this, 42 (39 on-effort) were confirmed as adult giant devil rays. The mean group size was 1.2 animals $(\mathrm{SD}=0.6$; range $=1-4)$.

Adult giant devil rays were mostly $(88 \%)$ observed in the central and southern Adriatic Sea, whereas sightings of other "Myliobatiformes" were more frequent $(65 \%)$ in the northern portion of the basin (Fig. 1). The distribution of sightings was more clumped offshore in the central stratum than in the southern stratum.

Of the 23 (17 on-effort) 'other' Myliobatiformes encounters, only 7 could be identified to the level of family (6 myliobatids and 1 dasyatids).

\section{Abundance}

Figure 4 shows the distribution of perpendicular distances for all Myliobatiform sightings combined. There were fewer sightings close to the track-line than would be expected but the maximum sighting distance was relatively small, with a severe drop in sightings after about $236 \mathrm{~m}$ (at $40^{\circ}$ declination angle). The best fit was to a uniform model with a truncation distance of $225 \mathrm{~m}$; this effectively equates to a strip census. The variance in density was affected more by group encounter rate $(90 \%)$ than by group size $(10 \%)$, as apparent from the clustered distribution of sightings (Fig. 1). The uncorrected CDS abundance estimates for confirmed adult giant devil rays for the central and southern Adriatic are shown in Table 2, along with the uncorrected estimate for all rays for the whole Adriatic

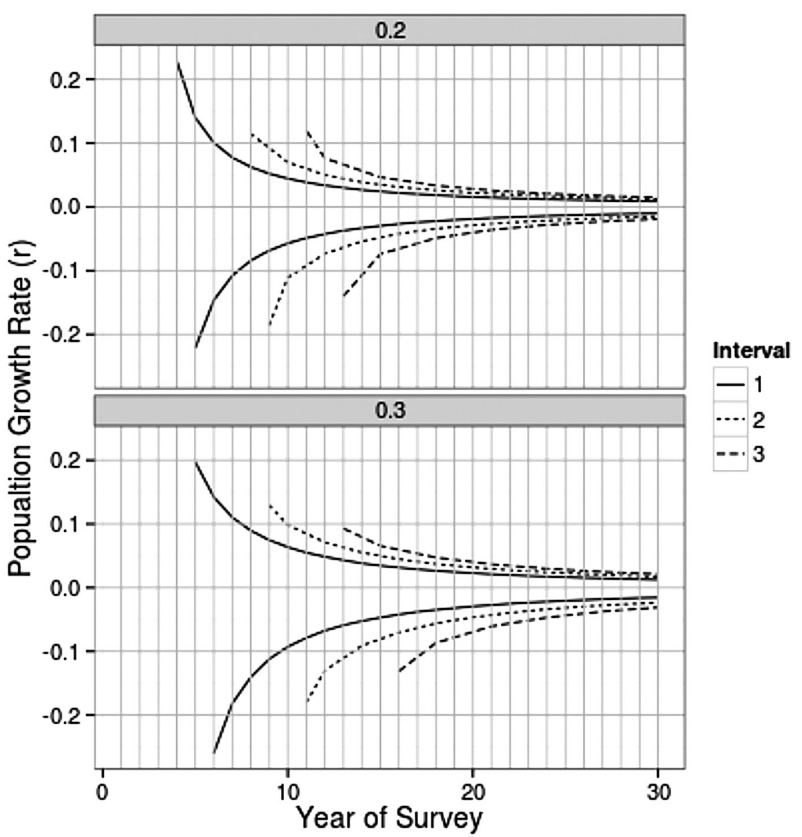

Fig. 5. - Power analysis: contours correspond to a probability of 0.6 that the null hypothesis (i.e. no change in the population) will be rejected when the null hypothesis is false. Panels correspond to the assumed $\mathrm{CV}$ of the survey abundance estimate $(0.2$ and 0.3$)$ and lines to annual, biennial and triennial survey cycles. Horizontal lines correspond to a given population growth rate and where this intercepts a power curve the number of years required before a change in the population is detectable can be read off the x-axis.

Sea. When we applied the availability correction factor $(0.49 ; \mathrm{SD}=0.25)$ to the uncorrected estimate $(\mathrm{N}=1595$; $\mathrm{CV}=0.23$ ) for confirmed adult giant devil rays, the estimated abundance increased to 3255 with a substantially larger $\mathrm{CV}(\mathrm{CV}=0.56)$.

\section{Population growth rate analysis}

Table 3 summarizes the results of the sensitivity analysis for the exploratory population modelling exercise. The 'base case' gave a population growth rate of 0.036 and a population doubling time of 19.5 years. Increasing $M$ or $k$ has a similar effect since $M$ is a function of $k$, i.e. population doubling time increases to 135 years. The analysis shows that the population growth rate and doubling time are very sensitive to the assumed parameters, i.e. a $25 \%$ increase in recruitment leads to a 7 fold increase in $r$.

\section{Power analysis}

Figure 5 shows the results of the power analysis for two levels of survey CV (20\% and 30\%) and two survey frequencies (1, 2 and 3 years). CVs of this level

Table 2. - Results of CDS uncorrected abundance estimates for adult giant devil rays and Myliobatiformes in general; DS, group density; D, animal density. CV and 95\% CI are given in parenthesis; * strip-transect with right truncation at $225 \mathrm{~m}$.

\begin{tabular}{|c|c|c|c|c|c|}
\hline Species & Effort $(\mathrm{km})$ & DS (groups $/ \mathrm{km}^{2}$ ) & $\mathrm{D}$ (animals $/ \mathrm{km}^{2}$ ) & Uncorrected abundance estimate & Model \\
\hline \multicolumn{6}{|c|}{ Central and southern Adriatic only $\left(88400 \mathrm{~km}^{2}\right)$ - giant devil ray } \\
\hline Adult giant devil ray & 3700 & $\begin{array}{c}0.016 \\
(21.4 \% ; 0.010-0.024)\end{array}$ & $\begin{array}{c}0.018 \\
(22.6 \% ; 0.011-0.028)\end{array}$ & $\begin{array}{c}1595 \\
(22.6 \% ; 1010-2,519)\end{array}$ & Uniform* \\
\hline \multirow{3}{*}{ Dasyatids } & \multirow{3}{*}{5600} & Adriatic Se & $33000 \mathrm{~km}^{2}$ ) - all rays & & \multirow{3}{*}{ Uniform* } \\
\hline & & 0.016 & 0.019 & 2,301 & \\
\hline & & $(20.5 \% ; 0.010-0.023)$ & $(21.2 \% ; 0.011-0.026)$ & $(21.2 \% ; 1509-3509)$ & \\
\hline
\end{tabular}


Table 3. - Summary of sensitivity analysis; $k$ is the growth coefficient from the von Bertalanffy growth equation, $M$ is the assumed level of natural mortality and recruitment is a function of births and first-year mortality $\left(M_{0}\right)$.

\begin{tabular}{lccc}
\hline Scenario & $\begin{array}{c}\text { Scaling } \\
(\%)\end{array}$ & $r$ & $\begin{array}{c}\text { Doubling time } \\
\text { (years) }\end{array}$ \\
\hline Default & 75 & 0.036 & 19.5 \\
$k$ & 125 & 0.053 & 13.5 \\
$k$ & 75 & 0.005 & 134.2 \\
$M$ & 125 & 0.067 & 10.6 \\
$M$ & 75 & 0.005 & 134.2 \\
Recruitment & 125 & 0.009 & 75.6 \\
Recruitment & 0.059 & 12.1 \\
\hline
\end{tabular}

are plausible if uncorrected estimates are considered as relative abundance estimates, and if it can be assumed that availability and perception bias remains constant over the survey periods investigated. The curved lines represent a power of 0.6 to detect a trend in the population for each combination of survey $\mathrm{CV}$ and frequency. For a given $r$ (y-axis), the time taken to detect a significant change in the population can be found from the intercept of the corresponding horizontal line with the power curves. For example, for a $\mathrm{CV}$ of $20 \%$ and an $r$ of 0.1 with surveys every 1,2 or 3 years it would take 6,7 and 10 years, respectively, to detect a change in the population. In contrast, detection of a growth rate of -0.1 would take longer, i.e. 7,10 and 14 years, respectively. With growth rates of between 0.05 and -0.05 it appears difficult to detect any change in the population within a reasonable timeframe.

\section{Behaviour}

On 14 August 2010, a group of four giant devil rays was observed northeast of the Otranto strait. Three animals had an estimated DW of about $3 \mathrm{~m}$ and one appeared to be smaller (Fig. 2). Animals were observed for about 6 minutes swimming in anticlockwise circles. During this observation the small individual and one of the larger animals engaged in belly-to-belly swimming and flipping over while circling. Such behaviour in Myliobatiformes is usually connected with courtship and mating (Tricas 1980, Yano et al. 1999).

\section{DISCUSSION}

\section{Distribution}

The present study is the first to provide a more quantitative and systematic description of the summer distribution of the giant devil ray (and information on some other Myliobatiformes) in the Adriatic. The results can be used to consider its distribution within certain biogeographic partitions of a Mediterranean sub-region: i.e. coastal, deep pelagic and intermediate ecosystems (Bianchi 2007). We recognize that this survey represents a seasonal snapshot for a single year. However, this is the first step towards having sufficient data to undertake a spatial modelling approach to better understand the key oceanographic and ecological factors that influence its distribution or an ERA to assess the impacts of fisheries.
Data from the present survey (Fig. 1) generally agreed with the information from earlier opportunistic data with more animals in the central and southern parts of the Adriatic (Notarbartolo di Sciara et al. 2006, Holcer et al. 2013).

Sighting records for other Myliobatiformes [i.e. the benthopelagic bull and common eagle rays (Bauchot 1987)] were more common in the shallower northern Adriatic, where local studies often detected them at high densities (Fortuna et al. 2010, Manfredi et al. 2010). It should be noted that these may include some sub-adult Mobula as referred to earlier under species identification.

The northwestern Adriatic generally has more turbid waters (e.g. Justić 1988, Bernardi Aubry et al. 2004). It is possible that this turbidity could have diminished the ability of observers to spot the key morphological features used for identification of the giant devil ray, especially for younger specimens. While in principle this may render the observed spatial segregation between giant devil rays and other Myliobatiformes (Fig. 1) an artefact, we do not believe this to be the case. Given the number of sightings identified to species and the clear differences in average size, we believe that the observed difference in distribution pattern is likely to be real and reflect the ecology of this species.

Both eagle and bull rays feed mainly on bivalves, gastropods and demersal crustaceans (Jardas et al. 2004, Dulčić et al. 2008). Despite the limited direct information on giant devil ray diet, the genus Mobula is believed to have a highly specialized diet, feeding on macro-zooplankton and predominantly euphausiids (Orsi-Relini and Cappello 1992, Sampson et al. 2010). This fits well with the distribution data available from the survey (Šipos 1977).

\section{Abundance}

As concerns the quantitative estimate of summer abundance of giant devil rays (and indeed Myliobatiformes) in the Adriatic Sea, the limitations of the study have been described and explain the high CV for the availability-corrected estimate. The estimate is only partially corrected and underestimates the actual abundance to an unknown extent for two main reasons: (1) the lack of data to correct for "perception bias" (which may be high given the need for good condition to see and identify them); and (2) the fact that possible unidentified sub-adult giant devil rays are among the 26 smaller ray sightings. The partially corrected estimate of 3255 ( $\mathrm{CV}=0.56)$ may be considered to challenge the existing general perception of the 'rarity' of the giant devil ray. In absolute terms, a middle estimate of over 3000 animals would not be considered 'rare' as suggested in Holcer et al. (2013). Note that while the species may not be considered 'rare', this does not mean that the population has no conservation problems.

In addition, it should be noted that given the total surface area of the central-southern Adriatic (about $88400 \mathrm{~km}^{2}$ ), our estimate represents a maximum density of about 4 adults per $100 \mathrm{~km}^{2}$. It is difficult to 
evaluate how this density relates to the IUCN qualitative evaluation that this species is present in "very low densities' throughout its range (Notarbartolo di Sciara et al. 2006). Finally, any full consideration of status would need some knowledge of 'pristine' densities.

\section{Management implications and questions}

The giant devil ray is 'protected' in most Mediterranean countries and thought to be of limited commercial value (Bauchot 1987). That being said, as discussed above, there is information suggesting a recent directed fishery (e.g. in Israeli and Palestinian waters) and, possibly considerable ongoing incidental catch with various types of fishing gear for other target species.

There is considerable uncertainty over the status and present trends of the giant devil ray population, despite its presence in the appendices of various conventions and its 'Endangered' IUCN Red List classification. While the present study suggest that the species may not be not as rare as previously thought (the ban on pelagic driftnets since the early 1990s may have been successful in promoting population recovery), it is not known whether the population(s) is/are increasing, decreasing or static under the present conditions. As yet there is no research or management regime in place to evaluate this. If commitments to international agreements are to be kept, progress must be made, especially in the light of newly identified source of mortalities (e.g. Couturier et al. 2013). In addition, there is no information on what the original size of the population was in the 1970s before the "driftnet era" and no agreement on an appropriate conservation objective e.g. a biomass reference point corresponding to 'good conservation status' or an agreed desired (and reliably measured) trend in abundance.

A fuller assessment of the impact of fishery-related mortality should be carried out by conducting an ERA in which the susceptibility analysis is stratified by management sub-regions and fishing métiers. To conduct the ERA and evaluate the likely and actual success of any mitigation management measures requires: (1) improved information on recruitment; (2) a time series of relatively precise indices of abundance; (3) information on stock structure (if any) and the geographic and temporal distribution of the species; (4) robust estimates of removal rates from potentially impacting fisheries; and (5) appropriate reference points.

An interesting approach to examining recruitment (i.e. taking into account 'natural' biological parameters and anthropogenic removals) is to monitor population indices directly through, for example, aerial surveys. The present study has shown that this is possible in principle for the Adriatic Sea. While effective monitoring of population trends in devil rays is possible, this will require a long-term commitment to a monitoring programme and aerial surveys are probably the most cost-efficient approach. Given the observed densities of the giant devil ray, an increase in the research effort (e.g. by increasing the number of transects) will decrease the CVs of the estimates and thus shorten the time needed to detect trends should they occur.

\section{ACKNOWLEDGEMENTS}

This work was funded by the Italian Ministry of Agriculture, Food and Forestry, the Italian Ministry of Environment, and the Croatian State Institute for Nature Protection. We are particularly grateful to the Croatian Natural History Museum, the Albanian Association for Protection of Aquatic Wildlife, the Institute for Marine Biology of Kotor from Montenegro, the Institute of the Republic of Slovenia for Nature Conservation and Morigenos-Marine Mammal Research and Conservation Society, which actively contributed to the success of this project by helping with logistic and coordination efforts. The research was carried out under valid research and flight permits issued by relevant national administrations (for Croatia the Ministry of Culture, the State Geodetic Administration, the Civil Aviation Agency and Air Traffic Control; for Montenegro the Ministry for Spatial Planning and Environment and the Ministry of Defence; for Slovenia the Ministry of the Environment and Spatial Planning; for Albania the Ministry of Environment, Forests and Water Administration, the Ministry of Public Works and Transport, and the Civil Aviation Authority). Special thanks are due to the ACCOBAMS Secretariat and National Focal Points. We are also grateful to Sajmir Bequiraj, Andrea Borić, Novak Čađenović, Jelena Knežević, Aleksandar Joksimović, Jelena Basta, Giancarlo Lauriano, Simone Panigada, Grgur Pleslić, Nikolina Rako, Robert Turk and Ante Žuljević for their various kinds of support during the survey, and to Stefano Focardi (CNR) for helping with the early exploratory analysis. We also thank two anonymous reviewers and Paolo Sartor, whose comments greatly improved this manuscript.

\section{REFERENCES}

Akyol O., Erdem M., Ünal V., et al. 2005. Investigations on Driftnet Fishery for Swordfish (Xiphias gladius L.) in the Aegean Sea. Tr. J. Vet. Anim. Sci. 29: 1225-1231.

Anonymous. 2006. Bollettino delle acque marino-costiere del Friuli Venezia Giulia, n. 03, luglio 2006, 2 pp.

Arrizabalaga H., Bruyn P. de, Diaz G.A., et al. 2011. Productivity and susceptibility analysis for species caught in Atlantic tuna fisheries. Aquat. Living Resour. 24(1): 1-12. http://dx.doi.org/10.1051/alr/2011007

Bauchot M.L. 1987. Requins, raies et autres batoidés. In: Fischer W., Bauchot M.L., Schneider M. (eds), Fiches FAO d'identification des éspèces pour les besoins de la pêche (Revision 1) Méditerranée et Mer Noire. Zone de pêche 37. Vol. 2. Vértébrés. FAO, Rome, pp. 768-885.

Bearzi G., Pierantonio N., Affronte M., et al. 2011. Overview of sperm whale Physeter macrocephalus mortality events in the Adriatic Sea, 1555-2009. Mamm. Rev. 41: 276-293. http:/dx doi.org/10.1111/j.1365-2907.2010.00171.x

Bernardi Aubry F., Berton A., Bastianini M., et al. 2004. Phytoplankton succession in a coastal area of the NW Adriatic, over a 10-year sampling period (1990-1999). Cont. Shelf Res. 24: 97-115. http://dx.doi.org/10.1016/j.csr.2003.09.007

Beverton R.J.H., Holt S.J. 1959. A review of the lifespans and mortality rates of fish in nature and the relation to growth and other physiological characteristics. Ciba Found. Colloq. Ageing 5: $142-177$.

Bianchi N.C. 2007. Biodiversity issues for the forthcoming tropical Mediterranean Sea. Hydrobiologia 580: 7-21. http://dx.doi.org/10.1007/s10750-006-0469-5

Bonhommeau S., Farrugio H., Poisson F., et al. 2010. Aerial surveys of bluefin tuna in the western Mediterranean Sea: Retrospec- 
tive, prospective, perspective. Collect. Vol. Sci. Pap. ICCAT 65(3): 801-811.

Bradai M.N., Capapé C. 2001. Capture du diable de mer Mobula mobular dans le Golfe de Gabes. Cybium 25: 389-391.

Bruni M. 2006. Historical account of the chondrichthyan collection of the Oceanographic Museum of Monaco. Cybium 30(4): $15-22$

Buckland S.T., Anderson D.R., Burnham K.P., et al. 2004. Advanced Distance Sampling. Oxford University Press, $416 \mathrm{pp}$.

Camhi M.D., Valenti S.V., Fordham S.V., et al. 2009. The Conservation Status of Pelagic Sharks and Rays: Report of the IUCN Shark Specialist Group Pelagic Shark Red List Workshop. Newbury, UK, IUCN Species Survival Commission Shark Specialist Group, 78 pp.

Canese S., Cardinali A., Romeo T., et al. 2011. Diving behavior of the giant devil ray in the Mediterranean Sea. Endang. Species. Res. 14: 171-176. http://dx.doi.org/10.3354/esr00349

Casale P., Freggi D., Basso R., et al. 2007. A model of area fidelity, nomadism, and distribution patterns of loggerhead sea turtles (Caretta caretta) in the Mediterranean Sea. Mar. Biol. 152:1039-1049. http://dx.doi.org/10.1007/s00227-007-0752-7

Casellato S., Sichirollo E., Cristofoli A., et al. 2005. Biodiversity of some rocky outcrops in the Gulf of Venice ("Tenue"). Biol. Mar. Mediterr. 12(1): 69-77.

Caswell H. 1989. Matrix population models: construction, analysis, and interpretation. Wiley Online Library. Sinauer Associates Inc., Sunderland, MA, $722 \mathrm{pp}$.

Celona A. 2004. Caught and observed Giant devil rays Mobula mobular (Bonnaterre, 1788) in the Strait of Messina. Annales Ser. Hist. Nat. 14: 11-18.

Cliff G., Anderson-Reade M.D., Aitken A.P., et al. 2007. Aerial census of whale sharks (Rhincodon typus) on the northern KwaZulu-Natal coast, South Africa. Fish. Res. 84: 41-46. http://dx.doi.org/10.1016/j.fishres.2006.11.012

Cortés E., Arocha F., Beerkircher L., et al. 2010. Ecological risk assessment of pelagic sharks caught in Atlantic pelagic longline fisheries. Aquat. Living Resour. 23: 25-34. http://dx.doi.org/10.1051/alr/2009044

Council Regulation (EC) No 199/2008 of 25 February 2008 concerning the establishment of a Community framework for the collection, management and use of data in the fisheries sector and support for scientific advice regarding the Common Fisheries Policy. Official Journal of the European Union, L 60/1, 5.3.2008.

Council Regulation (EU) No 57/2011 of 18 January 2011 fixing for 2011 the fishing opportunities for certain fish stocks and groups of fish stocks, applicable in EU waters and, for EU vessels, in certain non-EU waters. Official Journal of the European Union, L 24/1, 27.1.2011.

Council Regulation (EU) No 692/2012 of 24 July 2012 amending Regulations (EU) No 43/2012 and (EU) No 44/2012 as regards the protection of the giant manta ray and certain fishing opportunities. Official Journal of the European Union, L 203/1, 31.7.2012.

Council Regulation (EU) No 39/2013 of 21 January 2013 fixing for 2013 the fishing opportunities available to EU vessels for certain fish stocks and groups of fish stocks which are not subject to international negotiations or agreements. Official Journal of the European Union, L 23/1, 25.1.2013.

Couturier L.I.E., Marshall A.D., Jaine F.R.A., et al. 2012. Biology, ecology and conservation of the Mobulidae. J. Fish Biol. 80(5): 1075-1119. http://dx.doi.org/10.1111/j.1095-8649.2012.03264.x

Couturier, L.I.E., Bennett, M.B., Richardson, A.J. 2013. Mystery of giant rays off the Gaza strip solved. Oryx 47(4): 480. http://dx.doi.org/10.1017/S0030605313000793

Cushman-Rosin B., Gačić M., Poulani P., et al. (eds) 2001. Physical oceanography of the Adriatic Sea. Past, present and future. Dordrecht: Kluwer Academic Publishers, 320 pp. http://dx.doi.org/10.1007/978-94-015-9819-4

Di Natale A. 1998. By-catch of shark species in surface gear used by the Italian fleet for large pelagic species. Col. Vol. Sci. Pap. ICCAT 48(3): 138-140.

Di Natale A., Mangano A., Maurizi A., et al. 1995. A review on driftnet catches by the Italian fleet: species composition, observer data and distribution along the net. Col. Vol. Sci. Pap. ICCAT 44(1): 226-235.

Dulčić J., Lipej L., Orlando Bonaca M., et al. 2008. The bull ray,
Pteromylaeus bovinus (Myliobatidae), in the northern Adriatic Sea. Cybium 32(2): 119-123.

Dulvy N.K., Baum J.K., Clarke S., et al. 2008. You can swim but you can't hide: the global status and conservation of oceanic pelagic sharks and rays. Aquat. Conserv. 18: 459-482. http://dx.doi.org/10.1002/aqc.975

Ferretti F., Worm B., Britten G.L., et al. 2010. Patterns and ecosystem consequences of shark declines in the ocean. Ecol. Lett. 13: 1055-1071.

Fortuna C.M., Vallini C., Filidei Jr E., et al. 2010. By-catch of cetaceans and other species of conservation concern during pair trawl fishing operations in the Adriatic Sea (Italy). Chem. Ecol. 26: 65-76. http://dx.doi.org/10.1080/02757541003627662

Froese R., Pauly D. (eds) 2012. FishBase. World Wide Web electronic publication. www.fishbase.org, version (04/2012)

Gislason, H., Daan N., Rice J., Pope J. 2010. Size, growth, temperature and the natural mortality of marine fish. Fish Fish. 11: 149-158. http://dx.doi.org/10.1111/j.1467-2979.2009.00350.x

Gerrodette T. 1987. A power analysis for detecting trends. Ecology 68(5): 1364-1372. http://dx.doi.org/10.2307/1939220

Hobday A.J., Smith A.D.M., Stobutzki I.C., et al. 2011. Ecological risk assessment for the effects of fishing. Fish. Res. 108(2): 372-384.

http://dx.doi.org/10.1016/j.fishres.2011.01.013

Holcer D., Notarbartolo di Sciara G., et al 2007. Occurrence of Cuvier's beaked whales in the southern Adriatic Sea: evidence of an important Mediterranean habitat. J. Mar. Biol. Assoc. U.K. 87: $359-362$. http://dx.doi.org/10.1017/S0025315407055075

Holcer D., Lazar B., Mackelworth P., et al. 2013. Rare or just unknown? The occurrence of the giant devil ray (Mobula mobular) in the Adriatic Sea. J. Appl. Ichthyol. 29(1): 139-144. http://dx.doi.org/10.1111/jai.12034

IOR. 2011. Baza podataka i pokazatelja stanja morskog okoliša, marikulture i ribarstva. Stanje eutrofikacije [Database and indicators of the state of marine environment, mariculture and fisheries. Eutrofication status]. Institute of oceanography and fisheries/Environmental protection agency; Available online at http://jadran.izor.hr/azo/, accessed on 22.10.2011.

Jardas I., Santić M., Pallaoro A. 2004. Diet composition of the eagle ray, Myliobatis aquila (Chondrichthyes: Myliobatidae), in the Eastern Adriatic Sea. Cybium 28(4): 372-374.

Jensen A. L. 1996. Beverton and Holt life history invariants result from optimal trade-off of reproduction and survival. Can. J. Fish Aquat. Sci. 53(4): 820-822. http://dx.doi.org/10.1139/f95-233

Justić D. 1988. Trend in the Transparency of the Northern Adriatic Sea 1911-1982. Mar. Pollut. Bull. 19(1):32-35. http://dx.doi.org/10.1016/0025-326X(88)90751-5

Lazar B., Casale P., Tvrtković N., et al. 2004. The presence of the green sea turtle, Chelonia mydas, in the Adriatic Sea. Herpetol. J. 14: 143-147.

Lazar B., Lipej L., Holcer D., et al. 2008. Occurrence of the leatherback turtles Dermochelys coriacea in the eastern Adriatic Sea. Vie Milieu 58: 237-241.

Lazar B., Žuljević A., Holcer D. 2010. Diet composition of a green turtle, Chelonia mydas, from the Adriatic Sea. Nat. Croat. 19: 263-271.

Lorenzen K. 2000. Allometry of natural mortality as a basis for assessing optimal release size in fish-stocking programmes. Can. J. Fish Aquat. Sci. 57(12): 2374-2381. http://dx.doi.org/10.1139/f00-215

Manfredi C., Ciavaglia E., Isajlović I., et al. 2010. Temporal and spatial distribution of some elasmobranchs in the northern and central Adriatic Sea. Biol. Mar. Mediterr. 17(1): 254-255.

Marano G., Vaccarella R., Bello G., et al. 1983. Prime osservazioni sulla pesca di Xiphias gladius L. (Osteichtes) nel Basso Adriatico. Thalassia Salentina 13: 50-59.

Mollet H.F. 2002. Distribution of the pelagic stingray, Dasyatis violacea (Bonaparte, 1832), off California, Central America, and worldwide. Mar. Freshw. Res. 53(7):525-530. http://dx.doi.org/10.1071/MF02010

Notarbartolo di Sciara G. 1987. A revisionary study of the genus Mobula Rafinesque, 1810 (Chondrichthyes: Mobulidae) with the description of a new species. Zool. J. Linn. Soc. 91: 1-91. http://dx.doi.org/10.1111/j.1096-3642.1987.tb01723.x

Notarbartolo di Sciara G., Serena F. 1988. Term embryo of Mobula 
mobular (Bonnaterre, 1788) from the northern Tyrrhenian Sea (Chondrichthyes: Mobulidae). Att. Soc. Ital. Sci. Nat. Mus. Civ. St. Nat. Milano 129: 396-400.

Notarbartolo di Sciara G., Serena F., Mancusi C. 2006. Mobula mobular. In: IUCN 2013. IUCN Red List of Threatened Species. Version 2013.2. <www.iucnredlist.org >. Downloaded on 28 February 2011

Orsi Relini L., Cappello M. 1992. The fin whale and other large pelagic filterers as samplers of Meganyctiphanes norvegica. Rapp. Comm. Int. Mer Medit. 33: 264.

Peterson I., Wroblewski J.S. 1984. Mortality rate of fishes in the pelagic ecosystem. Can. J. Fish Aquat. Sci. 41(7): 1117-1120. http://dx.doi.org/10.1139/f84-131

Reynolds J.D., Jennings S., Dulvy N.K. 2001. Life histories of fishes and population responses to exploitation. In: Reynolds J.D., Mace G.M., Redford K.H., Robinson J.G. (eds), Conservation of exploited species. Cambridge University Press, pp. 147-168.

Rice J.C., Legacè E. 2007. When control rules collide: a comparison of fisheries management reference points and IUCN criteria for assessing risk of extinction. ICES J. Mar. Sci. 64(4): 718-722. http://dx.doi.org/10.1093/icesjms/fsm011

Roff D. 1984. The evolution of life history parameters in teleosts. Can. J. Fish Aquat. Sci. 41:989-1000. http://dx.doi.org/10.1139/f84-114

Rowat D., Gore M., Meekan M.G., et al. 2009. Aerial survey as a tool to estimate whale shark abundance trends. J. Exp. Mar. Biol. Ecol. 368: 1-8. http://dx.doi.org/10.1016/j.jembe.2008.09.001

Sampson L., Galván-Magaña F., De Silva-Dávila R., et al. 2010. Diet and trophic position of the devil rays Mobula thurstoni and Mobula japanica as inferred from stable isotope analysis. J. Mar. Biol. Assoc. U.K. 90(5): 969-976. http://dx.doi.org/10.1017/S0025315410000548

Šipos V. 1977. Distribution of euphausiids in the Adriatic Sea in autumn 1974 and spring 1975. Rapp. P.v. Reun. Commn. int. Explor. scient. Mer Mediterr. 24: 123-124.

Storai T., Zinzula L., Repetto S., et al. 2011. Bycatch of Large Elasmobranchs in the Traditional Tuna Traps (Tonnare) of Sardinia from 1990 to 2009. Fish Res. 109(1): 74-79. http://dx.doi.org/10.1016/j.fishres.2011.01.018

Thomas L., Buckland S.T., Rexstad E.A., et al. 2010. Distance software: design and analysis of distance sampling surveys for estimating population size. J. Appl. Ecol. 47(1): 5-14. http://dx.doi.org/10.1111/j.1365-2664.2009.01737.x

Tricas T.C. 1980. Courtship and Mating-Related Behaviors in Myliobatid Rays. Copeia 3: 553-556. http://dx.doi.org/10.2307/1444540

Vetter E.F. 1988. Estimation of natural mortality in fish stocks: a review. Fish. Bull. 86: 25-43.

von Bertalanffy L. 1938. A quantitative theory of organic growth (inquiries on growth laws. II). Hum. Biol. 10(2): 181-213.

Yano K, Sato F, Takahashi T. 1999. Observations of mating behavior of the manta ray, Manta birostris, at the Ogasawara Islands, Japan. Ichthyol. Res. 46: 289-296. http://dx.doi.org/10.1007/BF02678515

Zaccaroni A., Insacco G., Scaravelli D. 2007. New sightings of young Mobula mobular in Mediterranean Sea and first report on heavy metal content in their tissues. In: Book of abstract of the 11th Annual Science Conference European Elasmobranch Association 2007, pp. 20-20. 